\title{
The Underground Economy in Croatia
}

Ott, Katarina

Source / Izvornik: Occasional Paper Series, 2002, 6, 1 - 29

Journal article, Published version

Rad u časopisu, Objavljena verzija rada (izdavačev PDF)

https://doi.org/10.3326/ops.12

Permanent link / Trajna poveznica: https://urn.nsk.hr/urn:nbn:hr:242:549651

Rights / Prava: Attribution-NonCommercial-NoDerivatives 4.0 International/ImenovanjeNekomercijalno-Bez prerada 4.0 međunarodna

Download date / Datum preuzimanja: 2023-04-26

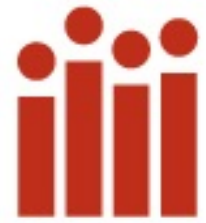

Repository / Repozitorij:

$\underline{\text { Institute of Public Finance Repository }}$

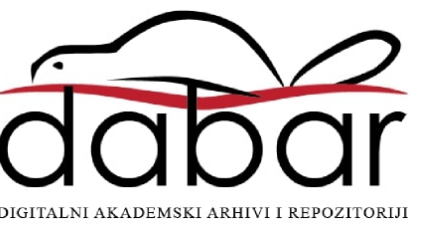


THE UNDERGROUND ECONOMY IN CROATIA

Katarina Ott

Occasional Paper No. 12

March 2002

(c) Institute of Public Finance 2002 


\title{
Katarina Ott
}

\section{The Underground Economy in Croatia 1990-2000}

\begin{abstract}
This article is a succinct description of research into the underground economy (UE) in Croatia in the 1990 to 2000 period. The circumstances surrounding and the reasons for the origin of the UE are explained, the dimensions of and changes in the UE are estimated at the level of the whole of the economy and in terms of certain industries. Also the socio-cultural and institutional dimensions of the UE are analysed, including the influence of formal and informal norms, privatisation, poverty, self-employment and so on. Various evaluation methods give different results - the national accounting discrepancy between income and expenditures method (below: national accounting discrepancy method) shows a growth of the UE from 1990 to a maximum of $37 \%$ of GDP in 1993 and a steady reduction to $7 \%$ of GDP in 2000 . In accordance with that method in the 1990-1995 period, the UE came on average to about 25\%, and in 1996-2000 to an average of $10 \%$ of GDP. The Eurostat method and estimates of tax evasion coincide with these trends, while two monetary methods and the consumption of electrical energy method show a rise in the UE in the 1995-1999 period, with trends at annual levels of between 22 and 34\% and a fall in 2000. With reservations because of the uneven results obtained by these various methods and because of uncertainty whether this is a matter of a genuine reduction of the UE or of an improvement in statistics, we nevertheless have to conclude that this research indicates that there has been a genuine reduction in the UE.

The results of the project indicate a negative correlation between the UE and GDP growth, then work "on the black" as the main reason for the UE, and the differentiation of statistical and economic reasons for the UE. Reasons for the reduction of the UE might be an improvement of the statistical system, a change in the structure of consumption, the introduction of VAT, the stabilisation of the large retail systems, the entry of foreign firms into the Croatian market, a change in the image of the government and so on. Unfortunately, there is still a lack of the kind of transparency and quality of public services that would have a considerable impact on the further reduction of the UE. The basic recommendation of this research is that for any reduction of the UE, it is more important to prevent the causes than to penalise the consequences, and in connection with this it is the institutional sphere that is crucial, the relationship of the government and the economy, i.e., the speed with which the government redefines its role in the market. Basic recommendations are also put forward for the improvement of institutions, for example, of the government, the process of privatisation, statistics, the tax system, the pensions system and so on.
\end{abstract}

JEL Classification: $\mathrm{O} 17$

Key words: the underground economy, Croatia 


\section{The Underground Economy in Croatia 1990-2000 ${ }^{1}$}

\section{Introduction}

In 1996 the Institute of Public Finance did research into the UE in Croatia in the 1990-1995 period. ${ }^{2}$ At that time we stressed the following: in all economies there is a part that is not included in the official economy (OE), i.e., its economic activities do not form a part of official statistics. The size and changes of the UE are important, because they can be a source of independent changes in the economy and can have an effect on the direction and strength of economic policy. The mostly probable share of the UE in the GDP of Croatia in 1995 was at least $25 \%$. Sector data were in accord with this calculated share and in 1994 covered a range of from $8 \%$ of GDP in industry to $68 \%$ of GDP in trade. In the $1990-1993$ period, the share of the UE in GDP rose. In the 1994-1995 period it was impossible to make any final judgement, because although most of the indicators suggested a fall, some important indicators actually pointed to an increase in the scope of the UE. Then we concluded that the share of the UE in GDP, of $25 \%$, was large and that it could be expected to stay equally large in the foreseeable future. Among reasons we stated the inherited tradition, the transition with its vigorous sector and institutional restructuring, the great influence of the government in the economy, particularly in privatisation. We also said that the high tax burden, and the renovation of growth and of the new enterprises might well further support the UE. We suggested detailed measures of economic policy necessary for the suppression of the UE, and particularly stressed that in attempts to reduce the UE it was more important to do away with the causes than to penalise the consequences. We also stressed the importance of the development of the institutional sphere, i.e., the relation between the government and the economy.

During 2001, the Institute of Public Finance went on with the previous research and started a new chapter in investigation of the UE in Croatia, ${ }^{3}$ this article in fact stemming from a number of papers created during this new research. In the first part of the article we attempt in brief to explain the circumstances and reasons for the origin of and a definition of the UE. The second, longest, part of the article relates to a measurement of the size of and changes in the UE. This second part is divided into two units. The first relates to the measurement of the UE at the level of the economy as a whole: through the national accounting discrepancy method, monetary methods, an adjusted Eurostat method, and estimates of tax evasion, and an assessment of the UE in certain industries: agriculture, industry and trade, tourism and foreign trade. The second unit covers the socio-cultural and institutional dimension of the UE that is the social and cultural

\footnotetext{
${ }^{1}$ The research project is published in Croatian in the journal "Financijska teorija i praksa", 26 (1), 2002., available at http://www.ijf.hr/finpraksa/index.htm

Author would like to thank the following colleagues for their cooperation at the 2001 research project: Predrag Bejakovic, Sanja Crnkovic-Pozaic, Nevenka Cuckovic, Andrea Domac, Michael Faulend, Davor Galinec, Nenad Karajic, Zeljko Lovrincevic, Sanja Madzarevic-Sujster, Sasa Madzarevic, Davor Mikulic, Biserka Niksic-Paulic, Ivan Rimac, Tihomir Stucka, Vedran Sosic, Aleksandar Stulhofer and Maja Vehovec.

2 The whole project has been published in the journal Financijska praksa, 21 (1-2), 1997, and a summary in Bicanic and Ott (1997); then came an international conference on the UE in transition, works from which were also published in Financijska praksa, 21 (5-6), 1997 and the book of Feige, E. L. and Ott, K. (1999).

3 Both pieces of research (that from 1996 and that from 2000) were financed in part by the Ministry of Finance, Tax Administration, Republic of Croatia.
} 
dimension, the effect of formal and informal norms, privatisation, poverty, self-employment, evasion of contributions for pensions insurance, and the judiciary. The third part of the article analyses the results of the measurement of the dimensions of and changes in the UE, while in the fourth part we offer recommendations for measures necessary for a reduction in the UE.

\section{The economic circumstances, reasons for the origin, and definition of the UE}

\subsection{The economic circumstances in Croatia}

Table 1: Basic economic indicators in Croatia 1994-2000

\begin{tabular}{|l|r|r|r|r|r|r|r|}
\hline & 1994 & 1995 & 1996 & 1997 & 1998 & 1999 & 2000 \\
\hline GDP, current prices (billion USD) & 14.2 & 18.1 & 19.8 & 20.1 & 21.6 & 20.1 & 19.0 \\
\hline Rate of growth of GDP (in \%) & 5.9 & 6.8 & 6 & 6.5 & 2.5 & -0.4 & 3.7 \\
\hline $\begin{array}{l}\text { Rate of growth of industrial } \\
\text { production (in \%) }\end{array}$ & -2.7 & 0.3 & 3.1 & 6.8 & 3.7 & -1.4 & 1.7 \\
\hline $\begin{array}{l}\text { Average number of unemployed (in } \\
\text { 000) }\end{array}$ & 243 & 241 & 261 & 278 & 288 & 322 & 358 \\
\hline $\begin{array}{l}\text { Rate of unemployment (Croatian } \\
\text { Employment Agency) }\end{array}$ & 14.5 & 14.5 & 16.4 & 17.5 & 17.2 & 20.8 & 21.1 \\
\hline $\begin{array}{l}\text { Rate of unemployment (International } \\
\text { Labour Organisation }\end{array}$ & 9.4 & 9.1 & 10.0 & 9.9 & 11.6 & 14.5 & 17.0 \\
\hline
\end{tabular}

Source: Data are from Table 1: Basic macroeconomic indicators of the Croatian economy, Monthly Statistical Review of the Ministry of Finance, save paragraph 2, which is from Table 11.1, GDP, annual calculation, Statistical Yearbook of the Republic of Croatia, National Statistics Office.

Although it might seem that they are already notorious facts, we shall endeavour to describe as briefly as possible the economic indicators in Croatia in the last few years.

In the 1994-1998 period, GDP rose from 14.2 to 21.7 billion USD, falling after that to 19 billion USD in 2000. Per capita GDP keeps up with the same trend and Croatia actually has a relatively low per capita GDP (around 4,200 USD in 2000). The rate of growth of GDP swings markedly (plus $6.5 \%$ in 1997 , minus $0.4 \%$ in 1999 , plus $3.7 \%$ in 2000). It is similar with industrial growth rates, only at a somewhat higher level.

The greatest economic headache in Croatia, of course, is unemployment, which from 243,000 in 1994 rose to 358,000 in 2000 . The rate of unemployment is constantly on the rise, from $14.5 \%$ in 1994 to $21.1 \%$ in 2000 , according to Croatian official data ${ }^{4}$, or from $9.4 \%$ in 1994 to $17 \%$ in 2000 according to the Labour force survey in line with the methodology of the International Labour Organisation (ILO).

These indicators should be borne in mind as the environment in which various phenomena related to making a living arise, one of them certainly being the UE.

\footnotetext{
${ }^{4}$ Number of persons registered as unemployed at the Croatian Employment Agency.
} 
countries

\subsection{Factors that affect the tendency towards the growth of the UE in transition}

Table 2. Factors that affect the tendency of the UE to rise in transition countries

\begin{tabular}{|l|l|}
\hline Factors & Source \\
\hline $\begin{array}{l}\text { political repression, inadequate legal system, institutional } \\
\text { weaknesses, administrative control and discretional } \\
\text { decision-making in the economy, high tax burdens, } \\
\text { macroeconomic instability and a non-payment culture }\end{array}$ & $\begin{array}{l}\text { Kaufmann and Kaliberda } \\
(1998), \text { North (1997), Vehovec } \\
(2001)\end{array}$ \\
\hline $\begin{array}{l}\text { non-functioning of property rights, high entrepreneurial risk } \\
\text { and high transaction costs }\end{array}$ & North (1997), Vehovec (2001) \\
\hline $\begin{array}{l}\text { wide ranging legislative and regulatory changes, enormous } \\
\text { redistribution of the national wealth, lack of existence or } \\
\text { ineffectiveness of institutions of public control }\end{array}$ & World Bank (2000) \\
\hline $\begin{array}{l}\text { lack of democratic, economic and regulative institutions, } \\
\text { absence of experience of paying taxes, discretionary rights } \\
\text { of public servants, governmental waste }\end{array}$ & Bejakovic (2001) \\
\hline
\end{tabular}

Although the UE does exist and develop in all countries, from the most developed to the most undeveloped, in the last few years particular attention has been attracted by the UE in the transitional countries. For these countries, it can be pointed out that higher rates of economic growth, lower rates of unemployment and the rapid development of the private sector can result in a rapid and successful transition, while lower rates of economic growth and a powerful role for the government in the redistribution can lead to a more sluggish and unsuccessful process of transition to the market. It is particularly dangerous if there are no or few democratic, economic and regulatory institutions. Such a background, in collusion with broad discretionary powers of public officials, can lead to corruption, lobbying and various forms of informal activities. Informal activities tend to make the manners of behaving that have arisen in the UE become the moving force not only in the underground sector, but also behind measures that are taken in the $\mathrm{OE}$, in the legal and political systems and so on. We have met such phenomena in the last ten years in all the transition countries, and they have been a great obstacle in the way of economic development and growth. The UE and corruption are encouraged by monopolies and discretionary decision-making, and they are limited by transparency, accountability and the responsibility of governmental and social institutions. Most dangerous are those points where the private and the public sectors coincide, because then the unregulated opportunities in the public sector lead to corruption that can have an effect on further social, political and finally economic regression. For this reason it is necessary to broaden the knowledge and awareness of all those taking part and of the public about the need for regularity, and to reinforce the legal background, moral values, market stimuli and the institutional framework.

In brief, as stated by Eilat and Zinnes (2000), the UE is the main feature of the dynamics of transition. Whether it will have a positive or negative role in the transition depends on the speed with which the government will redefine its role in the market.

\subsection{Defining the UE}

In our previous research (1997) most of the authors deal in detail with a definition of the concept of the research, and the term underground economy was used as a uniform term. However, even 
then, and especially over the course of time, it was clear that there was no black and white phenomenon, i.e., that it is sometimes difficult to differentiate the UE from the OE (Karajic, 2001). Explained through the institutional taxonomy, the problem is simple: the official economy implies compliance with the rules, and the underground economy implies non-compliance with the rules. And yet, in all economies, and especially in those in transition, there is a frequent dualism, that is, phenomena are more frequently grey than black and white. Once we accept this point of view, it is still more dangerous to accept the statement that rules of behaviour are transferred from the UE to the OE (Ott, 2000), because it is not only that they get transferred, rather they are diffused. Nevertheless, because of the inveteracy of the term and for the sake of connection with the previous project, in this text, although aware of the imprecision, we shall retain the concepts of $\mathrm{UE}$ and $\mathrm{OE}$.

Although we shall not here deal to any greater extent with the definition of concepts, we can nevertheless repeat the common definition (Feige, 1999) that depending on the regulations that are infringed differentiates illegal activities, i.e., forbidden production and distribution, unreported activities, i.e., above all the violation of tax regulations, and unrecorded activities, through which measurement in the national accounts is avoided. Of course, it is not always easy to draw the line, and activities often overlap.

Karajic (2001), depending on the respect for rules and legality of economic transactions, differentiates the official economy and the shadow economy; depending on the influence of the governmental regulations he divides the official economy into the corrupt and the uncorrupted, and at the same time the shadow economy takes in the corrupt from the OE, and adds to it the fictional and the criminal. Depending then on the extent of the failure to observe the regulations Karajic distinguishes the unreported, the unrecorded, the informal, the corrupt, the underground and illegal, the criminal. In the transition, particularly marked is the complementarity and continuousness of all formal and informal types of activity.

Although in a great deal of research it has been shown that there is a considerable connection between corruption (defined as abuse of the public service for personal profit) and the UE (e.g., Eilat and Zinnes, 2000), in this research we did not deal in particular with corruption. Measurements of corruption are on the whole fairly unreliable, and when we had once determined that corruption is the consequence, and the cause is the lack of transparency of the public sector, the large discretional rights of public servants, the inefficiency of the courts and so on, it seemed better to concentrate on the causes.

At the end of this part, in which we have defined the concepts, we can emphasise the most important consequences of the UE, which is distorted information, lack of governmental revenue, effects on efficiency (depending on whether it is good or bad regulations that are infringed), impact on distribution (the poorest and the richest are most apt to be involved in the UE), and the destruction of the fabric of society (more of this in Feige and Ott, 1999).

\section{The measurement of the size of and changes in the UE in Croatia}

In this project we have applied various approaches to the measurement of the UE: via the national accounts, monetary methods, labour force surveys, tax evasion. We have attempted to evaluate the UE in individual industries, e.g., in agriculture, industry and trade, tourism, foreign trade.

Here one should point out that comparisons of results obtained by different methods are very risky. From experience it can be said that the measurement of the UE via the national accounting discrepancy method, for example, always gives relatively low results, unlike monetary methods, which always give relatively high results. Table 3 best illustrates these diversities. 
Table 3: Comparison of the UE as measured by different methods (in \% of GDP, average for the period)

\begin{tabular}{|l|r|r|r|r|}
\hline \multicolumn{1}{|c|}{ Method } & Germany & $\begin{array}{c}\text { United } \\
\text { Kingdom }\end{array}$ & \multicolumn{1}{c|}{ Italy } & \multicolumn{1}{c|}{ USA } \\
\hline Surveys of households & - & - & - & 5.6 \\
$(1981-1985)$
\end{tabular}

Source: Schneider and Enste (2000).

Apart from the usual problems that show up in an attempt to compare various methods of measurement in various periods and in various countries, we also have a number of specific problems in Croatia as well.

The period of 1990-2000 in Croatia was marked by considerable changes in the statistical system (research methods, and the actual concept), discontinuity in different statistical research, high inflation in the early years, the creation of numerous new units with low statistical discipline, and the disappearance of large business systems.

The changes in the quality and scope of data from 1990-2000 make it difficult to be able to conclude with any certainty whether the sudden reduction in the UE was really a reduction in the UE or whether this was simply a better coverage of the OE thanks to better statistics in the national accounts. It is unfortunately hard to determine the effect of statistics on the results, particularly because of the lack of updating of the input-output tables. ${ }^{5}$

${ }^{5}$ In Croatia, input-output tables from 1987 are still last available. Since we warned of this in 1997 and on many other occasions, we can only stress once more the need for the elaboration of new tables, because only in this way can we have an impact on the statistical causes for the appearance of the UE. For this it will be necessary to make a detailed analysis and to change the forms that are used in the statistical monitoring of individual industries so as to ensure data at the level of local kind of activity units and data about the structure of intermediary consumption. The basic premise is the coordination of activities and readiness for these activities within the National Statistics Office. One encouraging item of news is that the national Budget for 2002 envisages resources for the making of the input-output tables, and 
Mikulic and Madzarevic (2001) stress the need for the distinguishing of the UE (as unrecorded income) in a statistical and economic sense because the causes of origin are different, and this is usually insufficiently stressed. There is most often generalised talk about the role of the institutions, and here this is clearly stressed. Among the statistical reasons it is not primarily the concealment of income for the purpose of evading taxes. On the contrary, a unit may act in line with the law, pay taxes, but still not be covered by statistical research, its income not being recorded in the statistical data within the GDP. This shows that the National Statistics Office has to improve its statistical system. Economic reasons imply a deliberate statement of income that is less than the real for the sake of the avoidance of the payment of tax, contributions and other costs related to the formalisation of the industry. In this region it is the tax authorities that have to work on measures for the suppression of the UE.

Let us look now what kind of results we obtained with measurements at the level of the entire economy, and of particular industries.

\subsection{Measurement of the size of and changes in the UE at the level of the economy as a whole}

\subsubsection{Measurement with the discrepancy in the national accounting method}

Madzarevic-Sujster and Mikulic (2001) attempt to estimate income made but not recorded with the discrepancy in the national accounting method.

The data up to 1995 are the revised data from the previous research (1997), considering the later officially published data that better cover individual components of the GDP in Croatia. For the period up to 1998 the methodology of estimation of personal consumption on the basis of the total supply of goods for personal consumption is applied, while for later periods, the results of surveys of household consumption carried out by the National Statistics Office are used. In order to confirm the consistency of the estimates obtained, 1995 and 1998 are dealt with additionally, with alternative methods. The discrepancies of the results obtained are negligible.

Thanks to improvements in statistics introduced in the meantime, the authors have checked out their results (Madzarevic-Sujster and Mikulic, 1997) for the 1990-1995 period, and determined that the UE in this period came to an average of $25.4 \%$ of GDP, which is within the limits of the earlier estimates (23.35 and $26.88 \%$ ). We can be particularly satisfied with the coincidence of the results, considering the statistical conditions in which the first investigation was carried out. For the 1996-2000 period, the UE is estimated at an average 10.4\%. Such results seem fairly logical. In the earlier period we had the war, hyperinflation, the beginnings of the transitions and reform, and in the second period stabilisation and the strengthening of the ethical and legal system. Of course, one has to ask again how much this is a real reduction in the UE, and how much a better statistical coverage of the $\mathrm{OE}$.

Once again also one should stress that the method of discrepancy in the national accounting gives lower estimates of the UE than most other methods. Although it has a number of drawbacks, the method does provide a general picture, and it can be considered the lower border for the share of the UE in GDP. It is a very good point of departure for complementation with alternative methods of UE estimation.

we can hope that the resources will really be used for this purpose and that in the next research, not only in the UE, we can arrive at much more reliable results. 
Madzarevic-Sujster and Mikulic (2001), just like Eilat and Zinnes (2000), have determined that in Croatia there is a negative correlation between the UE and GDP. In further research one should go further into the link between growth in official GDP, the level of restructuring and the UE, because this knowledge might help in throwing light on the causes of the UE.

Figure 1. Share of the underground economy in GDP (\% of official GDP)

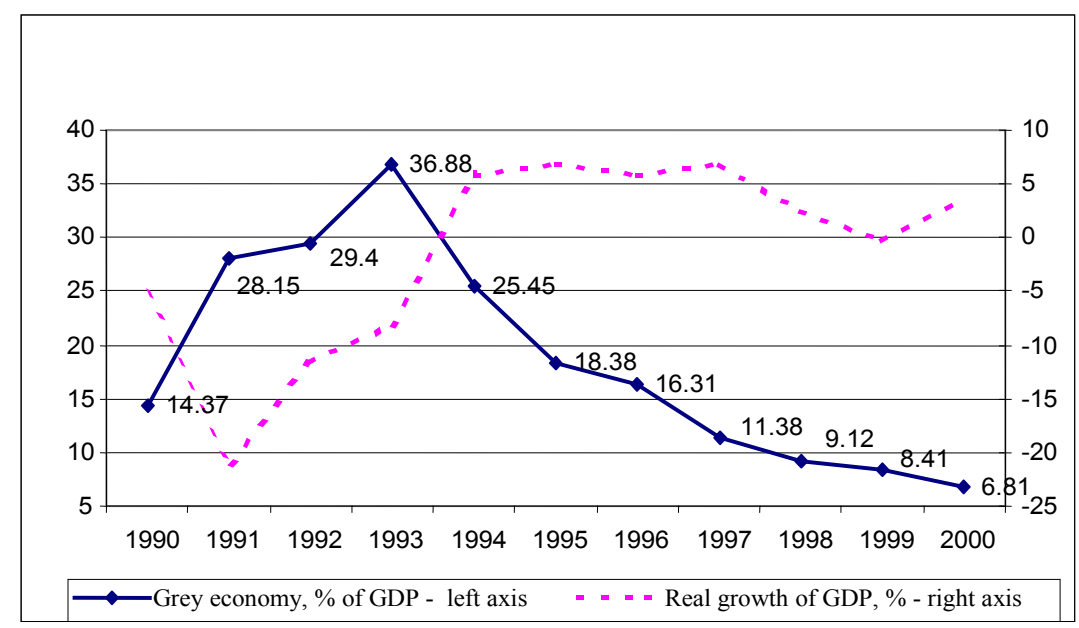

Source: Madzarevic-Sujster and Mikulic (2001).

\subsubsection{Measurements by monetary methods and the consumption of electricity} method

Monetary methods of the estimate of the UE are relatively simple, relatively reliable, but very questionable because of the rigid and arbitrary presumptions they are based on. They do not give any estimation of the absolute level of the UE, but can be used for an evaluation of its dynamics. Sosic and Faulend (2001) stress that the widespread dollarisation ${ }^{6}$ and the use of foreign cash in the UE is a particular obstacle to reliability of monetary methods (greater than reliance on empirically unconfirmed assumptions).

The authors think that in Croatia there are a number of problems that stand in the way of the application of monetary methods of measuring the UE, e.g. the short time series and the unsatisfactory statistical basis. Jankov too (1997) is of the same mind. Nevertheless Sosic and Faulend (2001) have attempted to estimate the UE:

1. testing the simple Gutman approach (ratio of domestic cash and deposits), and came to results that in the period of 1995 to 2000 vary between 25 and $34 \%$, with a rising trend,

2. on the basis of an estimate of the amounts of foreign cash in circulation; the results also vary between 22 and $27 \%$, the trend being upwards again,

${ }^{6}$ Sosic and Faulend (2001) talk of unofficial dollarisation as distinct from the official acceptance of a foreign currency as a lawful means of payment. This is the use then of a foreign currency (not necessarily the dollar, but also the mark or the euro) as money in the local economy. 
3. through the method of electricity consumption; the results vary between 24 and $30 \%$, the trend being also upwards.

If all three approaches are compared, the inter-year variations are very high, but the UE constantly shows a rising trend.

Figure 2. Evaluation of UE dynamics

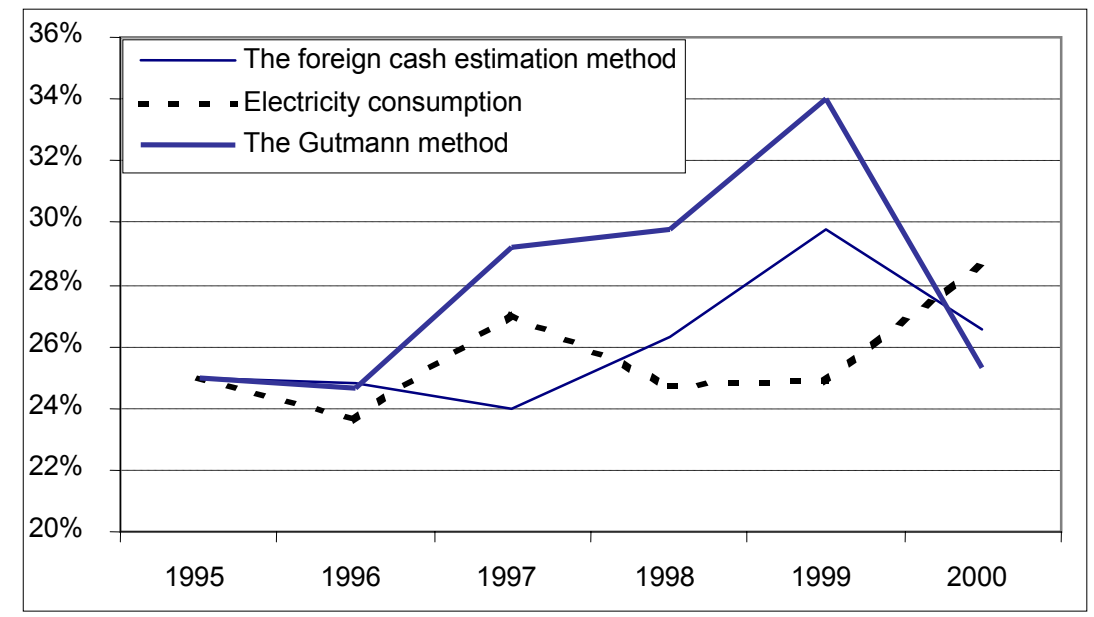

Source: Sosic and Faulend (2001).

Figure 3. Evaluation of UE dynamics, linear trends

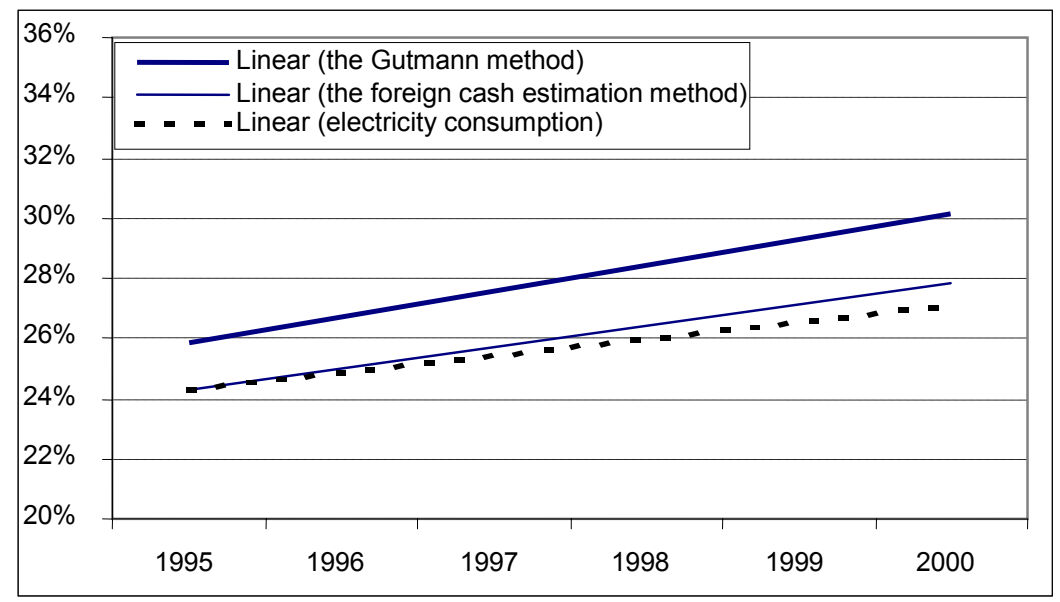

Source: Sosic and Faulend (2001).

As already pointed out, it is characteristic of various methods to give lower results (discrepancy of the system of national accounts) or higher results (monetary methods). Accordingly there should be no wonder that the results are so different. But how should one explain the differences in the trends? The Gutman method, used by Sosic and Faulend, does not take into account the specific features of a land like Croatia, in which there is an experience of hyperinflation and 
frequent devaluations, the citizens as a result being apt to turn their free resources into foreign currency and put them into short-term time deposits. This is not real saving, but delayed consumption stored in a currency in which there is more trust. If the share of cash in a somewhat wider monetary aggregate (between M1 and M4) than was used by Sosic and Faulend (2001) were investigated, i.e., if short term time deposits were included, the results would very likely be different (the share of cash would likely fall). ${ }^{7}$

In any case, considering the importance of foreign cash in circulation for the UEs of dollarised countries, which is the fact in all countries in transition, it is unusual that researchers do not put it at the centre of investigations of the UE, but still base their evaluations on data about the domestic money in circulation. The reason is perhaps the lack of existence of or poor reliability of data about foreign money in circulation, and the low level of knowledge about the real role of foreign cash in the UE.

The results from this method are perhaps questionable, but are certainly indicative. They are particularly of importance because Sosic and Faulend (2001) endeavoured to link up literature about the UE and dollarisation, suggesting this connection as a link that is missing, and which could enhance the quality of research into both areas. The paper more foregrounds the importance of dollarisation for UE research rather than it gives definite answers. Since the measurement of underground dollarisation is in its infancy, this work is one of the pioneer attempts that, we hope, will stimulate new research into the phenomenon.

\subsubsection{Measurements with an adjusted Eurostat method ${ }^{8}$}

Lovrincevic, Mikulic and Niksic-Paulic (2001) have estimated the UE according to the Eurostat ${ }^{9}$ method adjusted to the needs of transitional countries. Employment data from official sources and labour force surveys are compared. This method covers illegal activities such as prostitution, drug dealing and so on. The difference of the officially recorded and the expected rates of activity of the population is analysed. The expected rates are based on rates recorded in the reference years (when it is assumed there was no UE) or in reference countries (with a similar economic structure). The comparison takes various assumptions as its point of departure, and additional data from the labour force survey are also used as well.

With the use of the adjusted Eurostat method, in 1998 the UE came to 12.2 billion kuna, or $11.1 \%$ of the gross value added (GVA) or $8.9 \%$ of GDP, and in 1999 to 11.5 billion kuna, or $10.1 \%$ of GVA or $8.1 \%$ of GDP.

Because of the lack of adequately reliable indicators, assumptions are used that give a conservative estimate, that is, a lower limit for the UE.

${ }^{7}$ I owe this observation to Davor Mikulic.

${ }^{8}$ For the inclusion of this text in the project we are grateful to Ivo Sutalo of the National Statistics Office of the RC, which in 2001, in collaboration with the Economic Institute Zagreb, started a project to estimate the UE in RC according to the Eurostat methodology. Here the methodology and first results of the research are displayed. The authors have attempted to link the Eurostat approach with classical scientific methods so that interested readers should find it easier to see the differences and similarities of different scientific and statistical approaches during establishment of the scope of the grey economy in the RC during the 1998-1999 period.

${ }^{9}$ EUROSTAT is the statistical service of the EU; an abundance of interesting data can be found on their Web page:

http://europa.eu.int/comm/eurostat/Public/datashop/print-catalogue/EN?catalogue=Eurostat\&service=about catalogue 
The major part of the UE in Croatia (around 65\%) is related to non-reported labour, and in 1998 amounted to 8.2 of the 12.2 billion kuna, and in 1999 to 7.4 of 11.5 billion kuna.

The total UE in 1999 fell as compared with 1998, and its most important item also dropped unregistered employment. The fact that unreported work is the main source of the UE in Croatia shows that it is precisely this sector that should be focussed on in further research, along with the taking of appropriate measures of economic policy.

If we want to observe the share of the UE in individual industries, we cannot use percentage of GDP but percentage of GVA. ${ }^{10}$ Looked at according to industries, the share of the UE in 1999 was the greatest in trade (retail and wholesale) $(25 \%)$, health care $(14 \%)$, construction $(13 \%)$, fishery $(12 \%)$. The lowest share was in the public administration $(0 \%)$, agriculture and forestry $(0.4 \%)$, electrical supply industry $(1.4 \%)$. In absolute amounts, the greatest GVA was achieved in trade, 3.0 billion kuna, in the manufacturing industry, 2.5 billion, in transport and communications, 1.1 billion kuna.

The Eurostat method differentiates several forms of activity within the UE, for example, unrecorded for statistical reasons, unrecorded for economic reasons, informal, illegal and so on. Among the unrecorded for economic reasons there is a distinction between underreporting (income is underrated, the amount of intermediate consumption is overestimated, the aim being tax evasion) and non-reporting, or work on the black.

In Croatia the main component of the UE is work on the black, or unreported employment, but underreporting is not unimportant either. Underreporting actually very much depends on the size of the tax burden. In developed countries the penalties for unreported labour are very high, and the control system functions better than in Croatia, and thus here work on the black is more common than underreporting. More severe penalties for the non-reporting of labour and the government's writing off its claims from the past might result in underreporting rising and the non-reporting of workers falling. This is an expected trend in the structure of the UE as the transition process progresses.

\subsubsection{Estimate of tax evasion}

Since Lovrincevic, Mikulic and Niksic-Paulic (2001) state that non-reported labour is the main source of the UE, the estimate of tax evasion is particularly important. For the sake of an estimate of tax evasion Madzarevic-Sujster (2001) defines the UE as a legal economic activity that is not reported, for the sake of evading the payment of tax.

Madzarevic-Sujster (2001) finds the causes for the tendency towards tax evasion in the process of transition that created many changes in the taxation and the economic system. The rise in the overall tax burden is regularly accompanied by greater tax evasion, especially of income tax and contributions for social security. But an inappropriate legislative framework also has an effect on tax evasion, together with administrative obstacles, the credibility of the legal system, the quality of public services and so on.

From 1994 to 2000 the lower border of tax evasion shows a declining trend, from 8.5 to $5.5 \%$ of GDP, while the upper border up to 1998 was constant, and after that it fell from 11 to $7.5 \%$.

10 This is the only possible concept for a division according to industries because according to the existing calculation the GDP is calculated according to industries and in basic prices, and then the total net taxes on the products are added on (only at the level of the RC, and not on particular industries). 
Figure 4. Comparison of tax evasion and the share of the UE (\% of GDP)

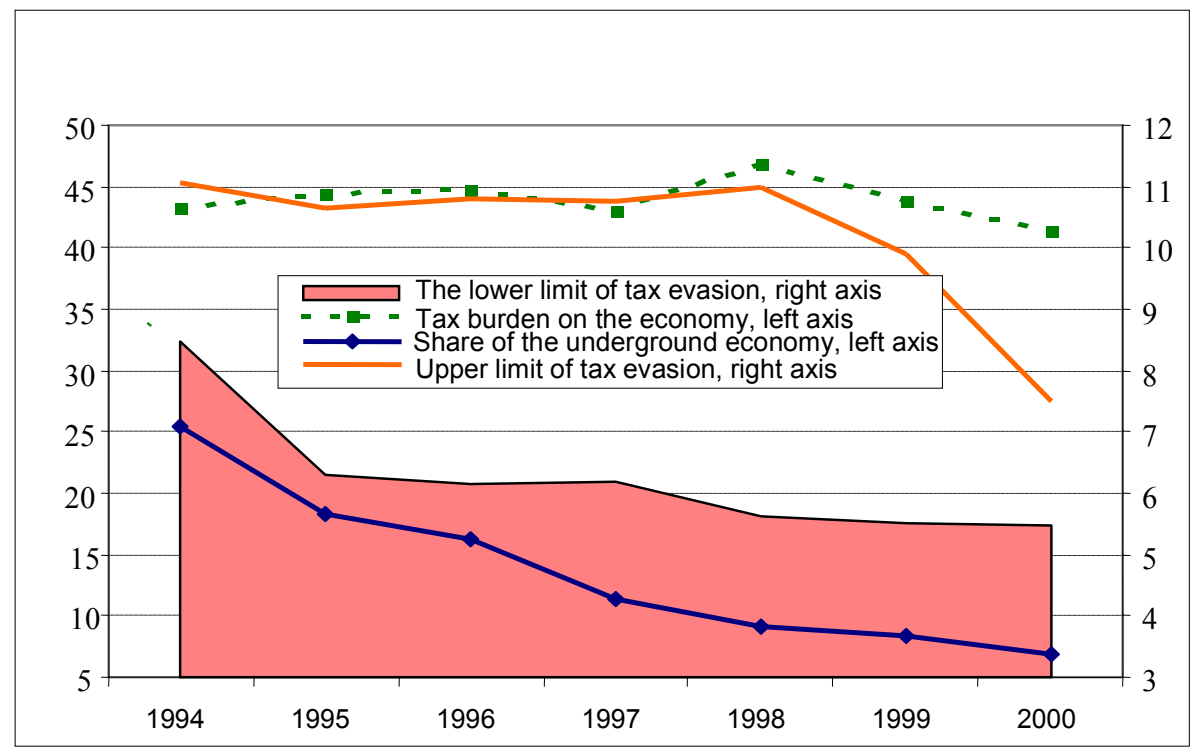

Source: Madzarevic-Sujster (2001).

It is interesting that the upper estimate of tax evasion follows the tax burden until 1998, the rise of the tax burden in 1998 led to the rise in tax evasion, and in 1998-2000 the reduction of the costs of labour resulted in a reduction of tax evasion.

Tax evasion is reducing, and we can be pleased with this. Nevertheless, 8.6 billion kuna (the lower limit) of missed revenue in 2000 is still a very large amount. The missed revenue is greater than, for example, the deficit of consolidated general government, which in 2000 came to 7.7 billion kuna. ${ }^{11}$ This means that the tax authorities, in their sphere of competence, and the government in all relevant segments, have to do all they can to keep on providing conditions that will lead to a reduction of the tendency towards the UE, that is, tax evasion. It is worth bearing in mind that it is easy to make a decision about going into the UE in an unstable environment, and for getting out of the UE a number of positive reforms and a relatively long period of time are required.

And here it is not enough just to step up fines. Large penalties, of course, do reduce the attractiveness of getting into the UE, but an increase of revenue from fines shows that the system is in a bad condition. For this reason it is more important to obviate the causes than to penalise the consequences.

\footnotetext{
${ }^{11}$ Ministry of Finance (2001).
} 


\subsubsection{Estimates of the $\mathrm{UE}$ in individual industries}

\subsubsection{Estimates of the $U E$ in agriculture, industry and trade}

Mikulic and Madzarevic (2001) have attempted to estimate the UE in three branches of the economy.

Agriculture. The results of the estimate are very stable for the whole of the 1990-1999 period, with an average lower limit of $6.8 \%$ and an upper limit of $16.9 \%$. Such weak oscillations are mainly the consequence of an inappropriate statistical basis and the lack of adaptation of the rural family budget survey.

Industry is a branch with a relatively low though growing UE trend, from $2.3 \%$ in 1996 to $5.2 \%$ in 1998. The results are lower than in the other branches, but one should recall the statement that the speed of the transition determines the height of the UE (Eilat and Zinnes, 2000), because the example of industry shows this best. As Mikulic and Madzarevic (2001) state, the growth or stagnation of the UE in industry, unlike the fall of the UE at the level of the economy as a whole, can be explained by the lagging of the transition in this activity. Small business and private initiative started earlier and more powerfully in trade and other service industries, which was manifested with a rise of the UE in such activities. With the development of competition and the stabilisation of the large systems, the UE starts to fall. The delay in the development of private enterprise and the transition to the market in industry can bring about a time delay in UE trends in industry.

Trade. Although, depending on the definition, the results of estimates of the UE in trade vary a good deal, the trends are nevertheless identical - a sudden growth in 1990-1993, a sudden fall in 1993-1994, a mild decline or stagnation from 1995 on. A negative correlation between GDP and the UE is noticed in trade in some years. This is yet another indication that more careful attention should be devoted to this phenomenon.

Figure 5. The UE in agriculture, industry and trade (\%)

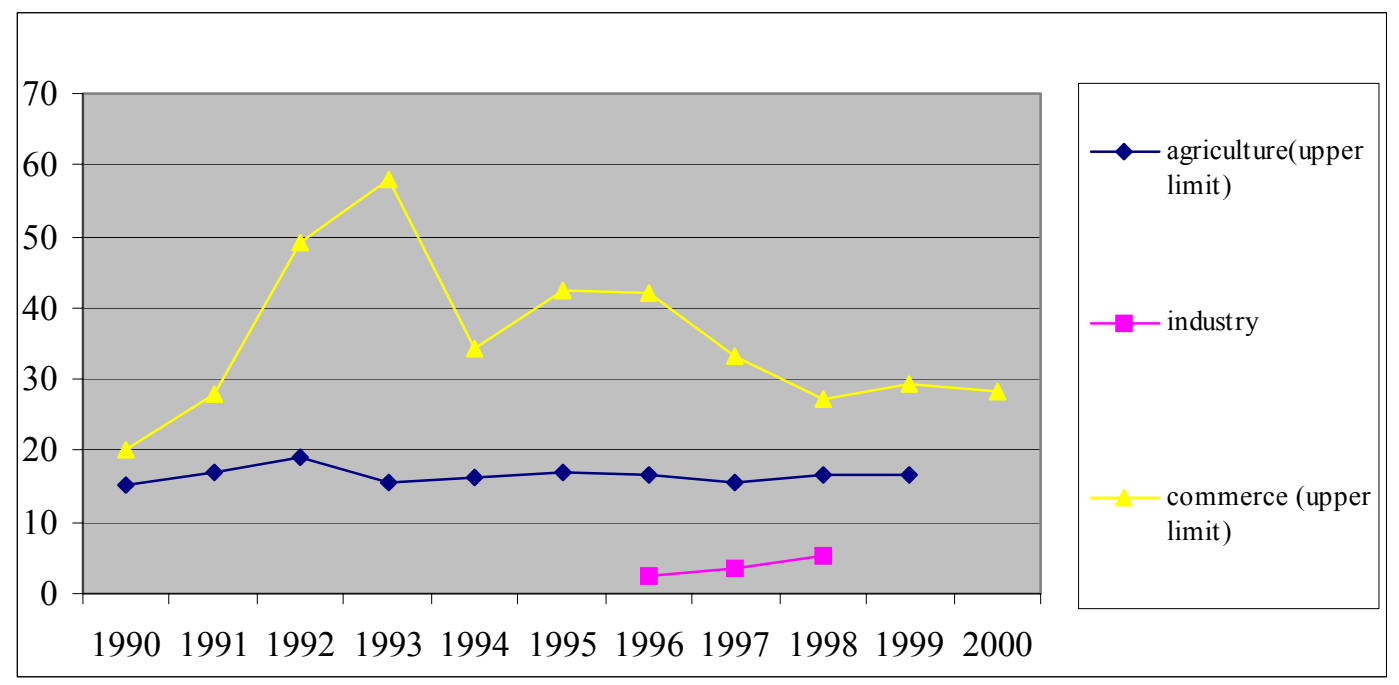

Source: Mikulic and Madzarevic (2001). 
In these three industries, for the whole of the decade, the ratio among them was the same - the UE is greater in trade, smaller in agriculture, and smaller still in industry. The trends, however, are essentially different: the UE is reducing in trade, stagnating in agriculture, but rising in industry. The explanation might be fairly simple - the speed of the transition per sector, the development of a number of new, mainly small business units and the number of employees, the relative weakening of the importance of the big systems. In short, the transition was most rapid in trade, slowest in industry - hence this kind of result. In agriculture there has been no transition, hence the stagnation. It is true, the already mentioned statistical limitations in agriculture do not allow reliable data to be attained.

If we wished to distinguish the economic and statistical effects on the size of the UE, it could be concluded that in trade it is both that are at work, while the economic are preponderant in industry, and in agriculture only the statistical influences are at work. This means that in a fiscal sense in trade large effects can be expected, smaller in industry, and the least of all in agriculture.

\subsubsection{Estimates of the $U E$ in tourism}

Stucka (2001), with a simple, well documented and pioneering approach, attempted to estimate the UE in tourism. Because of the different methodology, the results of this work are not comparable with the results of the previous research (Ivandic and Radnic, 1997).

Through a comparison with results of research in countries from which tourists come (Germany, Austria, Italy, Czech R., Slovakia and Slovenia) with the registered bed-nights in Croatia, Stucka calculated that the UE in the 1998-2000 period ranged from 18.6 to $28.8 \%$ of the registered total foreign bed-nights. This means that the forgone tax receipts of the government had risen from $0.4-0.6 \%$ of GDP in 1998 to $0.5-0.8 \%$ of GDP in 2000 .

According to the analysis of water consumption in and out of season the UE in 1998 ranges from 33 to $39 \%$ of the total bed-nights in private lodgings; in 2000 it ranges from 12 to $22 \%$. Expressed in percentage of GDP, the forgone tax receipts lie between 0.10 to $0.12 \%$ in 1998 , and $0.05-0.10 \%$ in 2000 .

Clearly, the results obtained should be taken with a reservation, precisely because of the number of pioneering approximations. Only a basic insight into the problem area is provided, and in future works these estimates need to be complemented with additional microeconomic knowledge.

Measurement via electricity consumption and the inflow of cash and cheques, although very interesting approaches, have not given the desired results, because of the inadequate quality of data. But with improvements of the statistics in some future research we can hope for more precise calculations with these methods too.

\subsubsection{The $U E$ in foreign trade}

On account of a poor foundation in statistics and documentation Galinec (2001) did not even attempt to assess the size of the UE in foreign trade, but drew attention to segments in which the UE might occur in foreign trade. These are money-laundering via foreign trade operations, false statement of the value of goods in customs declarations, the use of various customs rates during the import of similar products, the forgery of documents and bypassing the rules about the origin of goods. 
In the work, the effects of the existence of customs relief and privileges on the UE are analysed, and the effects of lost customs and tax revenue are estimated; these came to $3.6 \%$ of total budgetary revenues in 1998 and 1999 , and $2.2 \%$ in 2000 . For each form in which it appears, concrete recommendations are made to those in charge of trade, fiscal and overall macroeconomic policy, how to determine the existence and assess the dimensions of the UE, and how to work preventively. Guidelines are also offered for further research into the UE in foreign trade, particularly with respect to the efficiency of the customs authorities, money laundering, the fiscal effect of customs duties and the consequences that the reduction of profit tax has for the acquisition of comparative advantages.

Galinec (2001) gave a comprehensive systematisation of the problems and recommendations and with an improvement of the statistics, in the future it might be possible to set out on more concrete research on such bases.

\subsection{The socio-cultural and institutional dimensions of the UE}

\subsubsection{The socio-cultural dimension of the $\mathrm{UE}$}

Stulhofer and Rimac (2001) start out from the widely accepted assumption that the causes and dynamics of the UE cannot be understood outside the social and economic background of the area, in which the economic and cultural conditions create unique premises for the actions of individuals. This means that the reduction of the UE is necessarily based on the simultaneous action of social and cultural, legal and economic measures.

The Stulhofer and Rimac $(2001)^{12}$ paper, which is a direct continuation of the previous analysis (Stulhofer, 1997), starts off from the theoretical assumption that the dynamics of social opportunism coincides with the dynamics of the UE, since the rise in opportunism reduces moral costs. This, in turn, increases the readiness to get round or break the standards and - if it goes unpunished - sustains the expansion of opportunism.

If we compare the results from 1995 and 1999, we will notice the following:

- The level, in both diffusion and intensity, of opportunism has decreased. The number of those who think that tax evasion and bribe can never be justified has doubled. But the fact still is that $46 \%$ of respondents were prepared in certain circumstances to tolerate these phenomena.

- The age structure of opportunism has remained unchanged - the youngest age group is still most apt to justify tax evasion and taking bribes. This gives ground for concern suggesting that the phenomenon might be long-lived.

- Distrust in institutions has increased, and is once again most pronounced among the young.

- Economic traditionalism has ceased to be a relevant factor; respondents are getting used to differences in wages and are, as it seems, embracing the principle of individual responsibility.

Stulhofer and Rimac (2001) are relatively optimistic about the reduction of opportunism and the assumed increased moral costs of participation in the UE. They argue that the rise of distrust in institutions should be ascribed to the fact that during the first research work in 1995, trust in

12 The authors have endeavoured to measure opportunism (can the payment of bribes and the evasion of taxes be justified), lack of trust in institutions (the legal system and parliament), inclination towards economic traditionalism (increase or decrease levels in salaries), fondness for state paternalism (who should take care of the welfare and prosperity of citizens). 
institutions suddenly rose because of the political and military circumstances of the time (war victories in the Flash and Storm operations). Apart from that, they assumed that distrust in institutions precedes an opportunistic conception of reality, so the dynamics of the latter must be a better indicator of the UE. Since the level of opportunism has somewhat decreased, they suggest the corresponding reduction in UE. Of course, an opposite opinion is also possible - that inherited opportunism is the cause of lack of trust in institutions.

\subsubsection{Effects of formal and informal norms on the UE}

Vehovec (2001) stresses that the aim of economic development in a society is the construction of ethical norms that will reduce the costs of accepting, fulfilling and carrying out the law. These norms are formed in social life through upbringing, education and experience, creating a social capital that Fukuyama (1995) says is an additional resource, i.e., the ability of a nation to increase its economic potential. The creation of social capital cannot be resigned to spontaneous development. The government and institutions of government bear the responsibility for the construction of ethical norms. With their own ethical behaviour in the short term they can give a positive example, and over the long term they have to carry out reforms of the educational and judicial systems.

In connection with this the government can be protective or predatory in its effects (Mantzavinos, 2000 ). In the first case it will provide secure property rights and collect the fruits of the economic efforts of the citizens, and in the second it will manipulate property rights and take away their riches.

In a society there are both formal and informal institutions, which are interwoven, that is the informal usually complement the formal. In the transitional countries, the formal institutions are incompletely articulated, not built up, and some do not even exist. For this reason, it is the informal institutions that affect the (lack of) efficacy. The weakness of formal institutions contributes to the rise in the UE, crucial being an analysis of the costs and benefits of accepting (un)lawfulness. It is possible to observe the costs and benefits of unlawfulness, but also the costs and benefits of lawfulness. ${ }^{13}$ The rise in the UE indicates something of the weakness of the institutional framework that has not allowed the increase in the benefits to be greater than the increase in the costs of accepting lawfulness. For a change in the manner of behaviour, it is necessary to have formal stimuli (more consistent application of the laws) and informal stimuli (private support for contracts). In this, it is of particular importance for the laws to be credible.

\subsubsection{The $U E$ and privatisation}

Cuckovic (2001) treats the privatisation process that was in the 90s the background to the growth in the UE. Most activities of the UE in the first half of the 90s (Cuckovic, 1997), such as political clientelism, fictitious recapitalisation, failure to report or appropriation of the profits of firms, assets stripping, deliberate bankruptcies, corruption, bribery, abuse of official positions and so on went on in the second half of the 90s, with the new phenomena of irregularity in the privatisation of the banking sector and coupon privatisation.

Because of the absence of political will, the non-existence of an effective and independent judiciary and the inefficient public control, the UE was maintained in privatisation during the whole of the decade.

\footnotetext{
${ }^{13}$ Thanks for this mention to Vojo Franicevic.
} 
It is most interesting how the public appraised the effects of privatisation in 1998. The biggest winners were considered to be members of the then leading party HDZ, managers and politicians, and the greatest losers farmers, workers and professionals. In 1998 almost $30 \%$ of respondents expressed distrust in the Privatisation Ministry and the Croatian Privatisation Fund (only 5\% of citizens had any trust in these institutions), while between 1996 and 1998 there was a marked reduction in trust, and distrust in the legal system and the government of Croatia grew as well.

The structure of those who demanded a revision of ownership transformation also shows the public perception. Most demands for a review were made by the owners of nationalised and confiscated property, small shareholders and trade unions.

The reactions of the legal system were slow, and the first indictments were made only after the HDZ party was ousted although some cases had been investigated earlier; in the 1993-2000 period, however, $75 \%$ of crimes in the economic sphere that were reported were not prosecuted.

In its programme for 2000, the new government expressed its intention to improve the situation, but it concentrated on the legal framework for the revision of the privatisation process and not on the construction of appropriate institutions. A revision of the ownership transformation, unfortunately, is not the best of all solutions. On the one hand it is inadequate and inefficient, and on the other hand sends a bad message to investors and puts new uncertainties into the area of property rights. Instead of a revision of privatisation, broader institutional measures are required, especially those aimed at the prevention of any future such activities. Cuckovic (2001) offers an excellent review of concrete problems and concrete recommendations for the solution of them.

\subsubsection{The $U E$ and poverty}

Poverty, unemployment, the transition and the war are factors that must have had an effect on the aptitude to various informal forms of behaviour, and to taking part in the UE. Karajic (2001), then, dealt with a very interesting, important and so far completely neglected dimension in UE research in Croatia, and that is poverty.

According to World Bank research (2000), in line with international standards, the rate of absolute poverty, of $4 \%$, in Croatia is very low, but measured by the national standards, $10 \%$ of the population lives below the poverty line. The main economic causes of poverty in Croatia are the limited employment opportunities and an inappropriate welfare network. Thus for most of the poor the UE most often constitutes the only available possibility of making a living. Unfortunately the poor are involved in the UE less than those who are not poor. Thus it happens that in Croatia the UE does not reduce but rather increases existing social differences because the poor, because of increasingly weak education and lack of knowledge, do not manage to make use of the advantages of the UE even. These restricted opportunities keep the poor within this vicious circle and contribute to the long-lastingness of the phenomenon.

In brief, the following need stressing: (1) poverty is not the key generator of the UE, (2) the fact that the UE actually deepens inequality need not be equated with the creation of poverty and (3) a certain level of the UE in every developed society is related to the poorest but this is not the segment of the UE towards which social measures need to be directed.

\subsubsection{The UE and self-employment}

Karajic (2001) concludes that it is most important for employment to start to rise, because then, all those who are in the UE not from their own will but because it is the only way out will start to 
go over from the UE to the OE. With a rise in employment, the income of the population will rise and this will have an effect on a reduction in the UE.

Crnkovic-Pozaic (2001) starts out from the thesis that in the transitional countries business activities actually start in the UE and only then goes on in the OE. She studies persons who are self-employed in the UE, and unemployed persons who did work in the UE and then got involved in the Croatian Employment Agency Self-Employment Programme. During this she has tested the success of the programme and the difficulties that show up in a transition from the UE to the OE. The study of such programmes is most important, for if it could be shown that a large number of registered unemployed earn money in one way or another, that neither they nor their employers pay any kind of tax on these earnings, that all this is made possible by inappropriate regulations. Once we clear that, it would be much easier for the the media, politicians and the public to understand who among the unemployed is really at risk and how they should be assisted. Similarly, if it is shown that the self-employment programme is just a waste of money (it does cost more than DM 14,000 per employed person) and that the emphasis should be placed on the linking of enterprises with the existing industry and on a regional approach, then the problem of employment is turned into an organisational problem. ${ }^{14}$ It is crucial then, to determine the real level of unemployment, to reinvestigate the model of self-employment carried out recently and then either retain or reject it. The programme is without doubt expensive and is meant primarily for persons who anyway do have entrepreneurial abilities. The programme should be more effective considering the costs and help possible entrepreneurs to make a better estimate of the risks they are going to meet. Apart from this, it is necessary to bring in more thoroughgoing provision of information at the beginning of the programme, a tighter self-selection and selection processes.

\subsubsection{Evasion of retirement insurance contributions}

Since it is work on the black that is one of the main forms of the UE in Croatia the problems of contribution evasion deserve special attention. Bejakovic (2001) stresses that a propensity to evasion will be crucially affected by an inadequat link between contributions and pensions, an unjust system with many (high) privileged pensions, without the payment of contributions, and circumstances in which a contribution is not a condition for being able to claim pension rights. According to the Croatian Pension Fund (HZMO, 2001) in 2000 about 82\% of contributions were collected ( $73 \%$ from tradesmen and only $40 \%$ from farmers). Annually 2.5 billion kuna in contributions are not collected.

Some positive steps have already been taken, e.g., the collection of contributions by the Tax Administration, the expansion of the time range for the calculation of pensions and the development of the capitalised system, but many measures for improving collection are still required. Bejakovic (2001) states in detail many procedures that should be undertaken in the immediate future, related to legal provisions, the collection of contributions, the work of inspectors and so on. It is of particular importance to develop the feeling that the non-payment of contributions is not the heroic act of an individual and a manner of righting the wrongs of the government, but a shifting of the obligation to pay to someone else. In addition, one should strengthen the system by which information is given about general knowledge of public finances and the unsustainability of the existing situation in retirement insurance.

\footnotetext{
${ }^{14}$ Thanks for this observation to Dubravko Mihaljek.
} 
Not even pension reform of course will settle all the problems. The propensity to evade will continue to exist if e.g. the amount of the basis for the payment of contributions is unlimited, but the amount of pensions limited. In the same way, people will still be inclined to avoid pensions contributions when they understand that by private investment of the same sums they might get four to ten times a greater return from their money than they can expect from the pensions system (this calculation was obtained for example, by Siems, 2001). This will be the more marked the more people become aware of or educated about costs and benefits, and the banking and financial system is more trusted, and trust in the government, or expectations from it, weaken.

It can happen (in the countries of South America it does happen) that an employer does not pay in the contributions collected but retains them (temporarily or for ever). For this reason a good legislative background for the pension and investment funds is required, unbiased control (without political pressure and influences from interest groups), information about the importance and costs of public goods, the heightening of awareness that everyone has personally to bear part of the costs of his or her own pension rights and so on. The government should be more active, appearing on TV for example (which is publicly owned anyway) explaining why reform is necessary, what the financial situation in the pensions system is really like, what the role of the government is to be in the new system, what citizens need to be attentive of, what the government is undertaking to insure citizens, and what it does not guarantee them, and the extent to which it does not guarantee them this.

Without public awareness of the financial problems of the pensions system in the reform and of the necessary reduction of the rights of individual categories of insurees, considerable political resistance can be expected, which could drag out, and perhaps render impossible, any reform.

\subsubsection{Inefficacy of the judiciary}

Almost all authors who deal with the UE highlight the inefficacy of the courts as one of the incentives to the UE (for example Kaufmann and Kaliberda, 1996; Bicanic, 1997; De Soto, 2000; Krygier, 2001). Bejakovic and Domac (2001) attempt to study the situation in Croatia. Their analyses are of course made more difficult because of the inaccessibility and lack of completeness of the statistical data. For this reason their work only warns of some apparent problems while a real analysis will be possible only in some later research. In any event, they stress that it is important to encourage transparency in public tenders and contracts clearly to determine authorities and responsibilities of public servants and the opportunities they have for discretional decision-making. The courts can have their load lightened by the encouragement of arbitration of disputes. The adoption of clear intelligible, unambiguous and lasting laws, which will have an affect on the growth of the efficacy of the judiciary, greater resistance towards unlawful behaviour, the dissemination of the rule of law and democracy and, indirectly to a reduction of the UE and unlawful forms of behaviour.

Since a lot is being talked of the rule of law, we should mention Krygier (2001) who says that in a rule of law state the law counts, and in a state where the rule of law is strong it counts substantially. The best indicator of respect for the law is the measure according to which people who are supposed to be of some consideration keep to the law. These are the people and institutions that have the effective power - political, economic, social and religious. Conditions quite the opposite rule in societies in which, as Holmes says, "there is no rule of law until the Mafia needs lawyers". 


\section{The results of measuring the size of and changes in the UE in Croatia}

Well, then, what can we conclude after this research?

Figure 6. Estimate of the UE by various methods (\%)

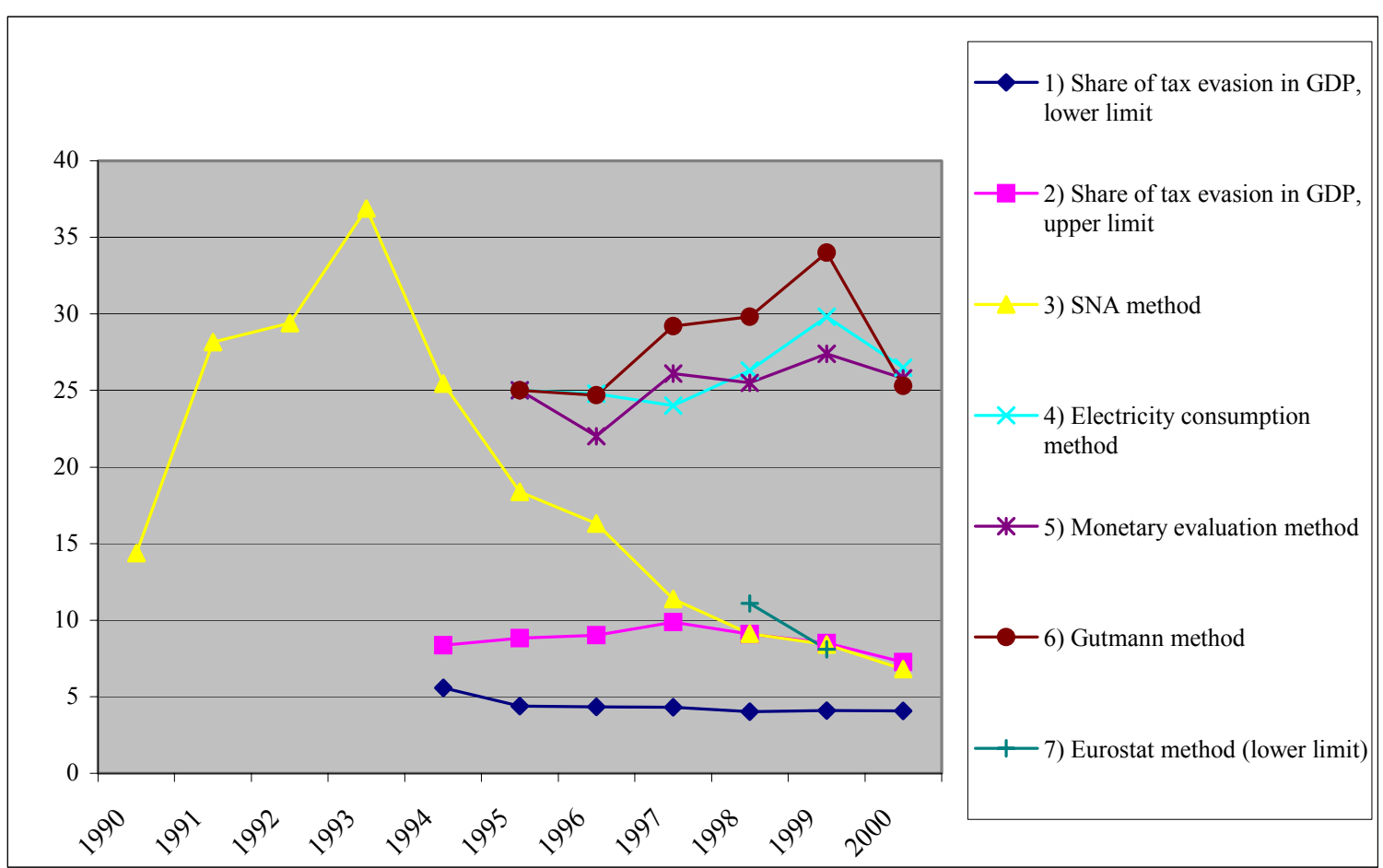

Source: Lovrincevic, Mikulic and Niksic-Paulic (2001), Madzarevic-Sujster (2001), Madzarevic-Sujster and Mikulic (2001), Sosic and Faulend (2001).

Measured by discrepancies in the national accounting (Madzarevic-Sujster and Mikulic, 2001) the UE shows a growth in the 1990 to 1993 period, when it reached a peak of almost $37 \%$ of GDP, and after 1993 recorded a constant fall to some less than 7\% of GDP in 2000. In the 19901995 period the UE came on average to about $25 \%$, and in the 1996-2000 period to an average of about $10 \%$ of GDP. The results seem fairly logical - the war, hyperinflation, the beginnings of the transition and reform in the first, and stabilisation and the strengthening of the ethical and legal system in the second period. The trend is very likely well depicted, yet the extent of the UE is probably overestimated in the first and underestimated in the second period. The Eurostat method too (Lovrincevic, Mikulic and Niksic-Paulic, 2001), through which results for only two years have been obtained very largely coincides with the discrepancy in the national accounting methods (8.9 as against $9.1 \%$ in 1998 , and 8.1 as against $8.4 \%$ in 1999). The lower level (unlike the upper limit for which there are some divergences) of tax evasion (Madzarevic-Sujster, 2001) in the 1994-2000 period is reduced, and it too coincides with the trends in the UE.

Writers who have analysed the social and cultural dimensions of the UE (Stulhofer and Rimac, 2001) are relatively optimistic to do with the reduction of opportunism and the assumed increase in the moral costs of taking part in the UE. Nevertheless, there is still some cause for concern here. Although the level of opportunism has decreased, it is still relatively high, with the youngest 
age group being the most inclined to it. In addition, distrust in institutions has increased, and is, again, most frequently encountered in younger respondents.

However, monetary methods (the ratio of domestic cash and deposits and the estimate of foreign cash in circulation) and the electricity consumption method (Sosic and Faulend, 2001) stand out from the trend described. In the 1995-2000 period the UE measured by these methods ranged from 22 to $34 \%$; the inter-year variations are very high but the UE on the whole shows a trend towards growth, except in 2000, when it started to fall.

Thus, as in the previous research (1997) once again it is hard to give very decided answers. Most methods suggest that the UE has diminished in recent years ${ }^{15}$ while monetary methods indicate a growth, except in 2000.

Once again, of course we can repeat that various methods do give different results; the monetary methods give inherently higher and the national accounting discrepancy method gives lower results. Thus we could explain the differences in the amount of the estimates, but how do we account for the differences in the trends? Very likely this is a shortcoming of the monetary method applied, for it does not take into account the particular features of countries like Croatia, in which the people, thanks to memories of times of inflation and devaluation have a different understanding of savings. In new research, monetary methods must be adjusted to Croatian conditions and cover the broader monetary aggregates in order to obtain a more precise image. Of course, for the moment, there are certain statistical preconditions that are missing.

Apart from that, we have to stress the fact that changes in the quality and scope of statistics in the 1990 to 2000 period make it difficult to conclude whether the reduction in the UE was really a reduction of the UE or simply a more thoroughgoing coverage of the OE thanks to better statistics in the national accounts.

Among the results we should certainly give prominence to the essential fact determined that in Croatia too there is a negative correlation between the UE and GDP (Madzarevic-Sujster and Mikulic, 2001, as well as Mikulic and Madzarevic, 2001). This is a factor on the basis of which it is necessary to move to further investigations, thanks to which we should be able to illuminate better the causes of the UE.

Also important is the understanding arrived at (Lovrincevic, Mikulic and Niksic-Paulic, 2001) that in Croatia the main component of the UE is work "on the black" while underreporting is less important. This means that further research should focus on just this segment, and that particular attention should be accorded in appropriate measures of economic policy. As the transition process goes on, we can expect a reduction of the share of work "on the black" and an increase in the amount of underreporting.

Sector evaluations too have confirmed the key thesis of the project that the speed of the transition determines the amount of the UE. In trade the UE is diminishing, in agriculture stagnating, while it is growing in industry. The reason for this is the fact that the transition was the fastest in trade, the slowest in industry, and did not exist at all in agriculture.

This research has stressed one more fact: the need to distinguish the statistical and the economic causes of the UE. This is a fact that is essential since it shows that it is necessary to work upon

${ }^{15}$ One of the indicators that the situation is improving is the report of Transparency International 2001 in which Croatia, according to level of corruption, went from 74th place in 1999 to 47 th in 2001. (http://www.transparency.org/documents/cpi/2001/cpi2001.html\#cpi) 
the statistical causes by improvements of the national statistics and on economic causes with improvements in the tax system and the efficacy of the tax authorities.

Accordingly, with certain qualifications because of the unequally results obtained with different methods, and because of doubts whether it is a matter of a real reduction in the UE or only of improvement of statistics we can nevertheless conclude that this research has pointed to a reduction in the UE.

Chronologically, Madzarevic-Sujster and Mikulic (2001) hold that the reduction of the UE in 1994 was affected by economic stabilisation; in 1995 by the improvement of the statistical base; in 1997 by the rise in incomes (which affected the change in the structure of personal spending, and thus there was a rise in spending on consumer durables which are on the hold financed with loans, which automatically reduces the possibility of concealing transactions), the consolidation of large commercial firms and the entry of foreign firms into Croatia (which resulted in the reduction of the competitiveness of small and informal enterprises); in 1998 by the introduction of VAT (which implies self-checking and the registering of transactions), and in 2000 by the reduction of unpaid debts, the consolidation of banking, increased loans to small and medium sized enterprises and so on.

In essence, the following might have had an effect on the reduction of the UE: improvements in the statistical system (methodology of calculating GDP) and the actual concept of total output; change in the structure of spending from personal to consumer durables (cars, flats) mainly bought with loans, implying fewer opportunities for the UE to work; tax reform, including the introduction of VAT; the stabilisation of large retail systems and the introduction of foreign firms into the Croatian market, resulting in the collapse of small and informal entrepreneurs who are more inclined to be involved in the UE; the change of the image of the government which implies payment, bankruptcy and distraint or execution, leading to a rise in tax morality and the reduction of the UE.

Unfortunately, key factors such as the transparency and quality of public services are still not developing with adequate speed, and quite a lot of time is still required for them to be improved.

\section{Recommendations of measures necessary for the reduction of the UE}

If we accept the assumption that an individual and/or company that is considering whether to operate in the UE or OE will act rationally and weigh the advantages - of not paying tax and contributions, avoiding the complicated regulations and corrupted government institutions and disadvantages - the impossibility of using public services such as the protection of property rights, the alleviation of trade and private services such as are provided by banks, the capital market, the non-banking financial institutions (Eilat and Zinnes, 2000) or the impossibility of advertising in the official media then it is relatively easy to determine in which way measures for the reduction of the UE or for the encouragement of activities within the OE should go.

The basic recommendation of both the previous (Ott, 1997; Feige and Ott, 1999) and this project is prevention of causes, not reaction to consequences. The UE is a serious phenomenon, and that is why the Institute of Public Finance has for several years been researching into related phenomena, e.g. the tax administration, tax burdens, compliance costs, the pensions system. ${ }^{16}$

\footnotetext{
${ }^{16}$ See for example Ott (1998), Ott and Bajo (2001), Kesner-Skreb (2001).
} 
Since we have already many times repeated more or less the same or very similar recommendations for economic policy measures related to the UE and further research into the $\mathrm{UE}^{17}$ we will not repeat them here. We shall merely stress that for a reduction in the UE it is more important to treat the causes than to penalise the consequences, and that it is the institutional sphere that is crucial in this, i.e. the relation between the government and the economy. For this reason it is necessary to improve laws and regulations, strengthen the independence and qualifications and equipment of the courts, improve statistics, the organisation, efficiency, qualifications of and cooperation among the governmental bodies, reduce the role of the government in the economy, rationalise public expenditure, improve the quality of the public sector, keep on with the implementation of reforms in the pensions system and also start off with reform of the healthcare system, as well as of the civil service, reduce the role of the government in the privatisation process, control the privatisation process and strengthen democratic forms of control.

Still, this time too we shall put forward certain concrete recommendations deriving from the works of all those involved in the project depending on the problems stemming from them, that is, on the area in which they show up, relating above all to an improvement in the institutions, i.e., the government, the privatisation process, statistics, taxes and so on.

${ }^{17}$ A number of recommendations, for both measures of economic policy and necessary further research, can be found in for example: Ott (1997), Bicanic and Ott (1997), Feige and Ott (1999), Ott [et al.] (2000). 
Box 1: Recommendations for measures for a reduction of the UE

\section{Short general recommendations}

- Better to obviate the causes than penalise the consequences.

- For a reduction of the UE, it is the institutional sphere that is crucial, the relationship between government and economy.

- It is essential to improve laws and regulations, step up the independence and capabilities of the courts, improve statistics, and the organisation, effectiveness and organisation of and coordination among the governmental bodies, reduce the role of the government, rationalise public expenditure, improve the quality of the public sector, go on with the implementation of the reform of the pensions system, as well as to start of the reform of the healthcare system and the civil service, to reduce the role of the government in the privatisation process, to control the privatisation process and strengthen democratic forms of control.

\section{General institutional measures}

- Strengthen political freedom, the legal system and institutional mechanisms for carrying out the laws, reduce administrative control and discretionary decision-making in the economy, cut the tax burden, strengthen macroeconomic stability and encourage the culture of paying.

- The government and the institutions have to bear the responsibility for the building up of ethical norms. Over the short term, they should be an example with their ethical behaviour, and over the long term they are obliged to carry out reforms of the educational and judicial systems.

- Encourage the functioning of property rights, which will reduce entrepreneurial risk and lower transaction costs.

- Encourage formal property rights, contracts and their credibility, especially the putting in order of the land registers, and also develop informal institutions to protect property rights and standards that will support trust and cooperation or cooperative behaviour.

- Provide a flexible labour market and expand educational opportunities which will have an effect on the speed of economic growth, reduction of poverty, rise in lower income group incomes, reduction of inequalities in the society, rise in tax revenue, which also mean more resources for welfare programmes.

- Long-term improvement of the institutional infrastructure of the market.

\footnotetext{
Measures in the privatisation process

- Undertake measures to step up the competitiveness of the private sector, put through better regulatory and judicial protection of property rights, especially of small stockholders, ensure obligatory transparency of the ownership structure of all joint stock companies and not only of those quoted on the stock exchanges improve the level of the quality of the Securities Commission and strengthen its independence, carry out decentralisation and deregulation, bring in a system of so-called positive sanctions, reform the public administration (ethical code in the civil service), carry out systematic scientific monitoring of the scope causes and consequences of the UE.

- Provide for broader institutional measures to increase the transparency and precision of the regulatory background, the efficiency of public control, the efficiency of the courts, the professionalism of the civil service, an anti-corruption system of values, a level of social cooperation and trust, and a reduction of the political clientelism, legality of operations of privatised firms improvement of corporate culture and a code of behaviour, reduction of the socio-cultural determinants and motives for working within the UE.
} 


\section{Measures in statistics}

- When the final data about the census are released in 2002, the National Statistics Office should in line with demographic trends estimate the overall population of the earlier years and revise the data for those years.

- Settle certain statistical problems to do with the relations between the National Statistics Office and Payments Clearing Institute and update the registers, ensure user response and the coverage of all industries.

- In order to be able to assess the UE in some industries (agriculture for example) it is necessary essentially to improve the statistical base and adapt the surveys about consumer spending.

- Organise a survey the main aim of which is to assess the size of the UE.

- The National Statistics Office has to improve the statistical system in order to reduce the statistical reasons for the existence of an UE, and the tax authorities have to try to suppress the economic reasons for the existence of the UE.

- Strengthen the role and credibility of the National Statistics Office, pass a law to define the policy of the publication of data, the structure of the gathering of data, step up the links between statistical branches, organise the gathering of data in such a way that the country and city statistical offices are financed within the context of the statistical system, and do not depend on local government budgets.

\section{Reform of the tax system}

- Because of the many changes in the tax system in Croatia in the last two years it is necessary to carry out a new reform to ensure a neutral tax system that does not have any effect on the making of economic decisions and in which the bases for taxation must be as broad as possible, with as few a number of exemptions and privileges as possible, and in which the tax system must not be used to carry out governmental social economic and development policies. Concretely, this means that no additional tax-breaks may be brought in for individual branches, regions or occupations, but on the contrary the aim should be to abolish privileges already existing.

- It is necessary to ensure a tax system that is stable as possible, a tax and regulatory burden as low as possible, to penalise evasion of taxes, to organise the tax service as well as possible, to increase the probability of the discovery of the tax evasion, to build up an appropriate structure of public spending and a quality of public services, and to strengthen the general awareness of the need to pay taxes.

\footnotetext{
Measures in the pensions system

- In the immediate future, re-examine, adjust and work on the legal provisions (e.g. the definition of pay, the upper limit for the obligation to pay contributions, the link between paying contributions and the amount of a pension and so on) systematically and determinedly to abolish exceptions and exemptions from paying contributions (especially in firms with financial troubles), to gather contributions and keep records in a more up-to-date and effective manner, to improve the statistical monitoring of the pensions system, to assess the burden of contributions and the possible amounts of pensions, improve the conditions of work, income, authorities and responsibilities of labour inspectors, consistently and rapidly to process and punish non-payment and irregular payment of contributions (again there is the question of the efficiency and promptness of the courts), develop the awareness that not to pay contributions is not a heroic act of an individual and a manner of righting governmental wrongs, but a shifting of the obligation of payment to someone else, and to strengthen the system of giving information about and the general knowledge about public finances and the unsustainability of the existing state in the pensions system.
} 
- Provide for a quality legal regulatory background for the pensions and investment funds, impartial supervision (without political pressures and the influence of interest groups), the provision of information about the importance and costs of the public good, the development of awareness that each person has personally to bear part of the costs of his own pension rights and so on. The government too should be more strongly involved, on the TV for example (anyway publicly owned) explaining why reform is necessary, the nature of the real situation in the pensions system, the role of the government in the new system, what citizens should pay attention to, what the government is doing to make insure its citizens, and what it does and does not guarantee them and to what extent.

\section{Encouragement of employment}

- Set up retraining centres in which it will be possible to acquire entrepreneurial, managerial and marketing skills and to develop the enterprise spirit necessary for starting off new production, and to create a network of agencies to help SMEs, spreading information about the opportunities for getting loans and about the financial markets, the new technologies, training opportunities and the like. It is particularly important to change the approach to education, which should provide contemporary knowledge, flexible workers, and a more mobile labour market.

The judiciary
- Encourage transparency in public tenders and contracts, clearly lay down the sphere of
competence and responsibility of public servants and their abilities to make discretionary
decisions. In concrete: transfer to the notaries public certain non-litigation procedures, which will
take some of the load off the courts, increase judges' wages, and those of court clerks, and to link
the opportunities for advancement and the gaining of further professional qualifications with
effectiveness, improve the territorial distribution of the courts (splitting big courts into several
smaller courts), equip the courts better, have specialised judges, improve cooperation with experts
of other professions, reconsider the Litigation Proceedings Law, build up the civil service by
founding a university studies of contemporary public administration, which would indirectly
have an effect on the changes of conditions in the judiciary, modernise the distraint procedure so
that creditors might obtain their rights more simply, and bring in alternative manners of settling
disputes - by external arbitration and conciliation out of court, and internal arbitration in the
courts, for which a law of arbitration still needs to be passed.




\section{Literature:}

BEJAKOVIC, P., 2001. Evazija doprinosa za mirovinsko osiguranje. Financijska teorija $i$ praksa, $26(1)$.

BEJAKOVIC, P. i DOMAC, A., 2001. (Ne)ucinkovitost sudbene vlasti u Hrvatskoj kao jedan od uzroka nesluzbenog gospodarstva. Financijska teorija i praksa, 26 (1).

BICANIC, I., 1997. Mjerenje velicina i promjena nesluzbenog gospodarstva. Financijska praksa, 21 (1-2), 15-29.

BICANIC, I. and OTT, K., 1997. The Unofficial Economy in Croatia: Causes, size and Consequences. Occasional paper, 1 (3), November. Available at http://www.ijf.hr.

CRNKOVIC-POZAIC, S., 2001. Nezaposleni koji rade: radnici i poduzetnici iz sjene. Financijska teorija i praksa, 26 (1).

CUCKOVIC, N., 1997. Nesluzbeno gospodarstvo i proces privatizacije. Financijska praksa, 21 (1-2), 259-277.

CUCKOVIC, N., 2001. Siva ekonomija i proces privatizacije u Hrvatskoj 1997-2001. Financijska teorija i praksa, 26 (1).

DE SOTO, H., 2000. The Mystery of Capital: Why Capitalism Triumphs in the West and Fails Everywhere Else? New York : Basic Books.

EILAT, Y and ZINNES, C, 2000. The evolution of the Shadow Economy in Transition Countries: Consequences for Economic Growth and Donor Assistance. CAER II Discussion Paper No. 83, September 2000., 70.

EGGERTSSON, T., 1999. Ekonomika institucija u tranzicijskim gospodarstvima. Financijska praksa, 23 (1), 63-95.

FEIGE, E. L., 1999. Institutions and Transition Economies; Confession of a Misguided Reformer, lecture at the Croatian National Bank, Zagreb, December 8, 1999.

FEIGE, E.L. and OTT, K., 1999. Underground Economies in Transition: Unrecorded Activity, Tax Evasion, Corruption i Organized Crime. Aldershot : Ashgate.

FUKUYAMA, F., 1995. Trust: The Social Virtues \& the Creation of Prosperity. New York: The Free Press.

GALINEC, D., 2001. Nesluzbeno gospodarstvo u vanjskoj trgovini. Financijska teorija i praksa, $26(1)$.

HZMO, 2001. Stanje sustava mirovinskog osiguranja i prijedlog mjera, interni materijal.

IVANDIC, N. i RADNIC, A., 1997. Nesluzbeno gospodarstvo u turizmu i ugostiteljstvu. Financijska praksa, 21 (1-2), 231-241.

JANKOV, Lj., 1997. Monetaristicki pristup nesluzbenom gospodarstvu. Financijska praksa, 21 (1-2), 157-169.

KARAJIC, N., 2001. Siromastvo i nesluzbeno gospodarstvo u Hrvatskoj - kvalitativni aspekti. Financijska teorija i praksa, 26 (1).

KAUFMANN, D., and KALIBERDA, A., 1996. Integrating the Unofficial Economy into the Dynamics of Post-Socialist Economies. Washington : World Bank. Available from: http://www.worldbank.org/wbi/governance

KESNER-SKREB, M., 1999. Uloga drzave u trzisnom gospodarstvu. Financijska praksa, 23 (2), 115-130.

KESNER-SKREB, M., 2001. Progressivity of Income Tax in Croatia During the 1995 to 1999. Main Findings. Financijska teorija i praksa, (25) 2, 152-158. available at http://www.ijf.hr. 
KRYGIER, M., 2001. Transitional questions about the rule of law. Why, what, and how? presented at the International Institute of Sociology 35th Congress, Jagiellonian University, 11-16 July, 2001. forthcoming in journal East Central Europe.

LOVRINCEVIC, Z., MIKULIC, D. i NIKSIC PAULIC, B., 2001. Pristup sluzbene statistike za procjenu nesluzbenog gospodarstva. Financijska teorija i praksa, 26 (1).

MADZAREVIC-SUJSTER, S., 2001. Procjena porezne evazije u Hrvatskoj. Financijska teorija $i$ praksa, 26 (1).

MADZAREVIC-SUJSTER, S. i MIKULIC, D., 2001. Procjena nesluzbenog gospodarstva sustavom nacionalnih racuna . Financijska teorija i praksa, 26 (1).

MANTZAVINOS, C., 2000. Individuals, Institutions and Markets. Cambridge : Cambridge University Press.

MIKULIC, D. i MADZAREVIC, S., 2001. Procjena neformalnog gospodarstva u poljoprivredi, industriji i trgovini. Financijska teorija i praksa, 26 (1).

MINISTRY OF FINANCE, 2001. Monthly Statistical Review, 71, September.

NORTH, D. C., 1997. The Contribution of the New Institutional Economics to an Understanding of the Transition Problems. WIDER Annual Lecture, No. 1. Helsinki : UNU/WIDER.

OTT, K., 1997. Gospodarska politika i nesluzbeno gospodarstvo. Financijska praksa, 21 (1-2), 29-45.

OTT, K., 1998. Tax Administration Reform in Transition: The Case of Croatia. Occasional paper, 5, April.

OTT, K., 2000. The Unofficial Economy and the State in Transition. Forthcoming in BARTLETT, W., BATEMAN, M., VEHOVEC, M. eds. Small Enterprise Develpment in South East Europe, Kluwer Academic Publisher.

OTT, K. [et al.], 2000. Public sector economics - The state of affairs, problems, and possible solutions. Newsletter, 2 (4), available at http://www.ijf.hr/newsletter.

OTT, K. and BAJO, A., 2001. Compliance costs in transitional economies - the Croatian experience. In: EVANS, C., POPE, J., and HASSELDINE, J. eds. Tax Compliance Costs: A festschrift for Cedric Sandford. Sydney: Prospect Media Pty Ltd.

SCHNEIDER, E. and ENSTE, D., 2000. Shadow Economies Around the World: Size, Causes and Consequences. IMF Working Paper, 26.

SIEMS, T. F., 2001. Reengineering Social Security in the New Economy, The Cato Project on Social Security Privatization, January 23, 2001, No.22.

SOSIC, V. i FAULEND, M., 2001. Dolarizacija i nesluzbeno gospodarstvo: slucajni partneri? Financijska teorija i praksa, 26 (1).

STUCKA, T., 2001. Nesluzbeno gospodarstvo u turizmu. Financijska teorija i praksa, 26 (1).

STULHOFER, A., 1997. Sociokulturni aspekti nesluzbenog gospodarstva - izmedju oportunizma i nepovjerenja. Financijska praksa, 21 (1-2), 125-141.

STULHOFER, A. i RIMAC, I., 2001. Oportunizam, institucije i moralni troskovi: sociokulturna dimenzija nesluzbenog gospodarstva u Hrvatskoj 1995-1999. Financijska teorija i praksa, 26 (1).

VEHOVEC, M., 2001. Nesluzbeno gospodarstvo i neformalne norme ponasanja: koliko etika u poslovnom ponasanju moze pomoci? Financijska teorija i praksa, 26 (1).

WORLD BANK, 2001. Croatia Economic Vulnerability and Welfare Study. Report No. 22079HR. 